\title{
Glutamate Input in the Dorsal Raphe Nucleus As a Determinant of Escalated Aggression in Male Mice
}

\author{
Aki Takahashi, ${ }^{1,2,3}$ Ray X. Lee, ${ }^{2,5,6}$ Takuji Iwasato, ${ }^{3,4}$ Shigeyoshi Itohara, ${ }^{7}$ Hiroshi Arima, ${ }^{8}$ Bernhard Bettler, ${ }^{9}$ \\ Klaus A. Miczek, ${ }^{10}$ and Tsuyoshi Koide ${ }^{2,3}$ \\ ${ }^{1}$ Laboratory of Behavioral Neuroendocrinology, University of Tsukuba, Tsukuba, Ibaraki, 305-8577 Japan, ${ }^{2}$ Mouse Genomics Resource Laboratory, \\ National Institute of Genetics (NIG), ${ }^{3}$ Department of Genetics, The Graduate University for Advanced Studies, and ${ }^{4}$ Division of Neurogenetics, NIG, \\ Mishima, Shizuoka, 411-8540 Japan, ${ }^{5}$ Department of Life Science, National Taiwan University, Taipei, 10617 Taiwan, ${ }^{6}$ Okinawa Institute of Science and \\ Technology Graduate University, Onna-son, Kunigami-gun, Okinawa, 904-0495 Japan, ${ }^{7}$ Laboratory for Behavioral Genetics, RIKEN Brain Science Institute, \\ Wako-shi, Saitama, 351-0198 Japan, ${ }^{8}$ Department of Endocrinology and Diabetes, Nagoya University Graduate School of Medicine, Showa-ku, Nagoya 466- \\ 8550 Japan, ${ }^{9}$ Department of Biomedicine, University of Basel, Basel CH-4056, Switzerland, and ${ }^{10}$ Departments of Psychology, Neuroscience, Pharmacology, \\ and Psychiatry, Tufts University, Medford, Massachusetts 02155
}

Although the dorsal raphe nucleus (DRN) has long been linked to neural control of aggression, little is known about the regulatory influences of the DRN when an animal engages in either adaptive species-typical aggressive behavior or escalated aggression. Therefore it is important to explore which neurotransmitter inputs into the DRN determine the escalation of aggression in male mice. Previously, we observed that microinjection of the $\mathrm{GABA}_{\mathrm{B}}$ receptor agonist baclofen into the DRN escalates aggressive behavior in male mice. Here, we used a serotonin (5-HT) neuron-specific $\mathrm{GABA}_{\mathrm{B}}$ receptor knock-out mouse to demonstrate that baclofen acts on nonserotonergic neurons to escalate aggression. Intra-DRN baclofen administration increased glutamate release, but did not alter GABA release, within the DRN. Microinjection of L-glutamate into the DRN escalated dose-dependently attack bites toward an intruder. In vivo microdialysis showed that glutamate release increased in the DRN during an aggressive encounter, and the level of glutamate was further increased when the animal was engaged in escalated aggressive behavior after social instigation. Finally, 5-HT release was increased within the DRN and also in the medial prefrontal cortex when animals were provoked by social instigation, and during escalated aggression after social instigation, but this increase in 5-HT release was not observed when animals were engaged in species-typical aggression. In summary, glutamate input into the DRN is enhanced during escalated aggression, which causes a phasic increase of 5-HT release from the DRN 5-HT neurons.

Key words: dorsal raphe nucleus; escalated aggression; $\mathrm{GABA}_{\mathrm{B}}$ receptor; glutamate; serotonin (5-HT); species-typical aggressive behavior

\section{Introduction}

The dorsal raphe nucleus (DRN) contains the largest accumulation of serotonin (5-HT) cell bodies in the brain, and it sends efferent projections to several distinct targets including the limbic structures and cortex (Hale and Lowry, 2011). Previous studies have identified neural activity in the DRN to be critical for aggressive behavior in several mammalian species (Jacobs and Cohen, 1976; Walletschek and Raab, 1982; Vergnes et al., 1986; Mos et al., 1993; Koprowska and Romaniuk, 1997; van der Vegt et al., 2003), and $5-\mathrm{HT}$ is the neurotransmitter which has been most strongly

\footnotetext{
Received June 16, 2014; revised Feb. 9, 2015; accepted March 17, 2015.

Author contributions: A.T., K.A.M., and T.K. designed research; A.T. and R.X.L. performed research; A.T., T.I., S.I., H.A., and B.B. contributed unpublished reagents/analytic tools; A.T. analyzed data; A.T., K.A.M., and T.K. wrote the paper.

This research was funded by KAKENHI $(23683021,25116527)$ and the Swiss National Science Foundation (31003A-152970). We thank Akira Tanave for the development of the software used to record behavior, and John Thomas Sopko for helpful advice.

The authors declare no competing financial interests.

Correspondence should be addressed to Dr Aki Takahashi, Laboratory of Behavioral Neuroendocrinology, University of Tsukuba, 1-1-1 Tennoudai, Tsukuba, Ibaraki, 305-8577 Japan. E-mail: akitakahashi@kansei.tsukuba.ac.jp.

DOI:10.1523/JNEUROSCI.2450-14.2015

Copyright $\odot 2015$ the authors $\quad 0270-6474 / 15 / 356452-12 \$ 15.00 / 0$
}

implicated in aggression (Coccaro et al., 1997; Kravitz and Huber, 2003; de Boer and Koolhaas, 2005; Miczek et al., 2007). The activity of serotonergic neurons in the DRN is modulated by 5-HT itself, as well as by GABA, glutamate, and other neurotransmitters (Adell et al., 2002). In contrast to the long-standing focus on 5-HT systems in the control of aggression, little is known about how the DRN 5-HT system is modulated when animals engage in species-typical or escalated aggression.

Previously, we have shown that pharmacological activation of $\mathrm{GABA}_{\mathrm{B}}$ receptors, but not $\mathrm{GABA}_{\mathrm{A}}$ receptors, in the DRN enhanced territorial aggression in male mice (Takahashi et al., 2010a,b). This manipulation caused animals to engage in longer aggressive bursts and to direct more attack bites at vulnerable body areas of male intruders (Takahashi et al., 2012). The DRN expresses high levels of $\mathrm{GABA}_{B}$ receptors (Bischoff et al., 1999), and almost all 5-HT neurons express $\mathrm{GABA}_{\mathrm{B}}$ receptors (Wirtshafter and Sheppard, 2001; Burman et al., 2003; Serrats et al., 2003). Electrophysiology and microdialysis studies have demonstrated that the application of the $\mathrm{GABA}_{\mathrm{B}}$ receptor agonist baclofen in the DRN inhibits 5-HT neurons (Tao et al., 1996; Judge et al., 2004). However, other studies, including our own, 
Table 1. Animals used in this study

\begin{tabular}{|c|c|c|c|c|c|}
\hline Experiment & Strain of resident & Intruder & Drug & Total animals used for analysis & Excluded \\
\hline 1 Intra-DRN baclofen & $\begin{array}{c}5-\mathrm{HTT}-\mathrm{GABA}_{\mathrm{B} 1}^{-/-} \\
\mathrm{CKO}(\mathrm{C} 57 \mathrm{BL} / 6 \mathrm{~J} \\
\text { background })\end{array}$ & (57BL/6) & Baclofen $(0.6,0.3 \mathrm{nmol})$ or aCSF & $11 \mathrm{WT}$ and $12 \mathrm{ck} 0$ & $\begin{array}{l}8 \text { missed placement, } 3 \text { stop } \\
\text { fight, } 2 \text { dead }\end{array}$ \\
\hline $\begin{array}{l}2 \text { Glutamate and GABA microdialysis } \\
\text { in the DRN during baclofen } \\
\text { administration }\end{array}$ & ICR & - & Baclofen $(0.6 \mathrm{nmol})$ or aCSF & 9 & 4 missed placement \\
\hline 3 Intra-DRN L-glutamate & ICR & ICR & L-glutamate $(0.1,1 \mu \mathrm{M})$ or aCSF & 10 & 1 stop fight \\
\hline $\begin{array}{l}4 \text { Antagonism of L-glutamate by } \\
\text { APV + NBQX }\end{array}$ & ICR & ICR & $\begin{array}{l}1 \mu \mathrm{M} \text { L-glutamate with/without } \\
50 \mu \mathrm{M} \mathrm{APV}+10 \mu \mathrm{M} \mathrm{NBQX} \text {, } \\
\text { or saline }\end{array}$ & 11 & $\begin{array}{l}3 \text { stop fight, } 6 \text { missed } \\
\text { placement }\end{array}$ \\
\hline $\begin{array}{l}5 \text { Glutamate microdialysis in the } \\
\text { DRN during aggressive encounter }\end{array}$ & ICR & ICR & - & 11 & $\begin{array}{c}3 \text { missed placement, } 2 \text { broken } \\
\text { probe, } 1 \text { stop fight, } 1 \text { sick }\end{array}$ \\
\hline $\begin{array}{l}6 \text { Glutamate microdialysis in the } \\
\text { DRN during instigation-height- } \\
\text { ened aggression }\end{array}$ & ICR & ICR & - & 10 & $\begin{array}{l}1 \text { missed placement, } 1 \text { stop } \\
\text { fight, } 3 \text { mechanical } \\
\text { problem }\end{array}$ \\
\hline $\begin{array}{l}\text { 75-HT microdialysis in the DRN } \\
\text { during aggressive encounter }\end{array}$ & ICR & ICR & - & 11 & 3 missed placement \\
\hline $\begin{array}{l}\text { 85-HT microdialysis in the DRN } \\
\text { during instigation-heightened } \\
\text { aggression }\end{array}$ & ICR & ICR & - & 11 & 1 missed placement \\
\hline $\begin{array}{l}\text { 95-HT microdialysis in the mPFC } \\
\text { during aggressive encounter and } \\
\text { instigation-heightened } \\
\text { aggression }\end{array}$ & ICR & ICR & - & $\begin{array}{l}9 \text { (1 animal without-instigation } \\
\text { only) }\end{array}$ & $\begin{array}{l}1 \text { damaged brain, } 1 \text { mechani- } \\
\text { cal problem }\end{array}$ \\
\hline
\end{tabular}

have shown that intra-DRN baclofen microinjections increased 5 -HT release in the DRN and in projection areas, such as the dorsal striatum or medial prefrontal cortex (mPFC) (Abellán et al., 2000; Takahashi et al., 2010b). Furthermore, the aggressionheightening effects of baclofen depend on the activation of 5-HT neurons in the DRN because these effects were blocked by coadministration of the 5- $\mathrm{HT}_{1 \mathrm{~A}}$ agonist 8-OH-DPAT, which acts on somatodendritic autoreceptors and inhibits 5-HT neural activity (Takahashi et al., 2010b). We hypothesized that the proaggressive effect of baclofen was mediated via $\mathrm{GABA}_{\mathrm{B}}$ receptors on nonserotonergic neurons within the DRN, which enhanced 5-HT neurotransmission.

In the present study, we first showed that baclofen acts on nonserotonergic neurons within the DRN to escalate aggression. The DRN receives glutamatergic input from many brain areas, such as mPFC and lateral habenula (Celada et al., 2001; Varga et al., 2003; Challis et al., 2013). Our results indicate that glutamatergic input to the DRN is critical for the escalation of aggression, induced by either pharmacological (baclofen) or behavioral (social instigation) means. Finally, we found that the enhanced input of glutamate in the DRN during escalated aggression, but not during species-typical aggression, led to increased 5-HT release in both the DRN and mPFC.

\section{Materials and Methods}

Animals. Male mice, aged 8-9 weeks at the beginning of aggression tests, were used as resident males (except 9-11 weeks for Experiment 1). Conditional knock-out mice on the C57BL/6J background were used for Experiment 1 (see details in the next section) and ICR/Jcl mice (CLEA Japan) for the other experiments (Table 1). Each resident male was pairhoused with a female (C57BL/6JJcl females for Experiment 1 and ICR/Jcl females for Experiments 3-9) for 3 weeks before the beginning of aggression tests in a polycarbonate cage $(22 \times 32 \times 13.5 \mathrm{~cm})$ with wood chips as bedding material. In Experiment 1, C57BL/6JJcl males (CLEA Japan), aged 7-9 weeks, bred and maintained at the National Institute of Genetics (NIG), were used as intruders. For Experiments 3-9, male ICR/Jcl mice were used as intruders, aged 5-8 weeks at the beginning of aggres- sion test, and instigators, aged 12-15 weeks. Intruder males and instigator males were housed in groups of five to seven per cage $(22 \times 32 \times 13.5$ $\mathrm{cm}$ ) with wood chips. Experiments 1-3, and 5-9 were conducted during the dark period at the NIG with controlled humidity and temperature $\left(50 \pm 10 \%, 23 \pm 2^{\circ} \mathrm{C}\right)$ on a $12 \mathrm{~h}$ light/dark cycle (lights off at 6:00 P.M.). Experiment 4 was conducted at the University of Tsukuba during the same dark period $\left(23 \pm 2^{\circ} \mathrm{C}, 12 \mathrm{~h}\right.$ light/dark cycle, lights off at noon $)$. Separate sets of animals were used for each experiment. Food and water were available ad libitum. All procedures were performed with approval from the Committee for Animal Care and Use of the NIG (permit nos. 23-10, 24-10, and 25-10) and the Animal Care and Use Committee at the University of Tsukuba (permit no. 14-391).

Mice with a 5-HT neuron-specific deletion of $G A B A_{B}$ receptors (Experiment 1). A conditional $\mathrm{GABA}_{\mathrm{B}}$ receptor allele in mice $\left(\mathrm{GABA}_{\mathrm{B} 1}\right.$ lox511/lox511) was developed at the University of Basel (Haller et al., 2004), and then backcrossed into C57BL/6J over 10 generations at Nagoya University. The 5-HT transporter (5-HTT)-Cre transgenic (Tg208) mouse expressing the Cre recombinase under the control of putative 5-HTT promoter in the RP23-39F11 BAC clone (Mizuno et al., 2014) was generated at RIKEN BSI (Arakawa et al., 2014, Suzuki et al., 2015). This mouse was generated and has been maintained on a C57BL/6J genetic background. $\mathrm{GABA}_{\mathrm{B} 1}$ lox511/lox511 and 5-HTT-Cre mice were crossed at the NIG to obtain $\mathrm{GABA}_{\mathrm{B} 1}{ }^{+/ \text {lox} 511} ; 5$-HTT-Cre ${ }^{+}$mice. Subsequently, we crossed these mice to $\mathrm{GABA}_{\mathrm{B} 1}$ lox511/lox511 mice to yield $\mathrm{GABA}_{\mathrm{B} 1}$ lox511/lox511; 5 -HTT-Cre ${ }^{+}$mice (referred to as $5-\mathrm{HTT}_{-} \mathrm{GABA}_{\mathrm{B} 1}{ }^{-1-}$ or conditional knock-out (cKO) mice in this paper) and $\mathrm{GABA}_{\mathrm{B} 1}$ lox511/lox511 $; 5$-HTT-Cre ${ }^{-}$ mice (wild-type control littermates; WT). Genotyping was conducted before weaning using ear punch samples.

Histology and immunostaining. To examine the expression of Cre protein in 5-HTT-Cre mice, we crossed 5-HTT-Cre mice with RNZ mice that in the presence of Cre protein express a nuclear localization signallacZ transgene inserted in the Rosa26 locus (Kobayashi et al., 2013). At 10 weeks of age, mice were deeply anesthetized with pentobarbital (97.4 $\mathrm{mg} / \mathrm{kg}$ somnopentyl; Kyoritsu Seiyaku) and intracardially perfused with $0.9 \%$ saline followed by Zamboni solution ( $4 \%$ paraformaldehyde mixed with $0.2 \%$ picric acid in PBS, pH 7.0). After postfixation in Zamboni solution for $2 \mathrm{~h}$, brains were cryoprotected in 30\% sucrose and frozen at $-80^{\circ} \mathrm{C}$. A cryostat was used to slice the brains into $40 \mu \mathrm{m}$ sections, which were stored at $-20^{\circ} \mathrm{C}$ until staining. To examine the colocalization of Cre 
protein with 5-HT neurons, we examined the expression of tryptophan hydroxylase (Tph) and a product of LacZ gene, $\beta$-galactosidase ( $\beta$-Gal), in the midbrain area. After $1 \mathrm{~h}$ of incubation with a blocking solution $(5 \%$ normal goat serum, $0.2 \%$ Triton $\mathrm{X}-100$ ) at room temperature (RT), sections were incubated with a mixture of primary antibodies (1:1000 mouse polyclonal anti-Tph antibody; T0678, Sigma-Aldrich), and $1: 1000$ rabbit anti- $\beta$-Gal polyclonal antibody (AB1211, Millipore) in the blocking solution overnight at $4^{\circ} \mathrm{C}$. After washing with PBS, the sections were incubated with a mixture of secondary antibodies conjugated to DyLight (anti-mouse DyLight 549 and anti-rabbit DyLight 488, both 1:400, Jackson ImmunoResearch Laboratories). Slides were coverslipped with Fluoromount (Diagnostic BioSystems) and microscopic analysis was done with a fluorescent microscope (Zeiss Axio Imager M1). To confirm lack of $\mathrm{GABA}_{\mathrm{B}}$ receptor-protein expression in DRN serotonergic neurons of 5-HTT-GABA ${ }_{\mathrm{B} 1}{ }^{-1-}$ mice, we double-stained for Tph (1:500, sheep polyclonal anti-tryptophan hydroxylase antibody AB1541, Millipore) and $\mathrm{GABA}_{\mathrm{B} 1}\left(1: 300\right.$, mouse monoclonal anti-GABA $\mathrm{B}_{\mathrm{B}}$ antibody ab55051, Abcam) in cKO and control WT mice. The procedure was the same as described above, with the exception that we used $2 \%$ normal goat serum with $0.5 \%$ Triton X-100 as blocking solution and the secondary antibodies were Alexa labeled (anti-mouse AlexaFluor 488 and anti-sheep AlexaFluor 555, both 1:600, Life Technologies).

At the end of all behavioral and in vivo microdialysis experiments, experimental mice were deeply anesthetized with pentobarbital and intracardially perfused with Zamboni solution, and their brains were removed, cryoprotected with sucrose, frozen, and sliced into $60 \mu \mathrm{m}$ sections. These slices were stained with cresyl violet to verify the placements of the cannula and the microdialysis probe.

PCR analysis of KO allele. To examine whether Cre-mediated excision of exon VII and VIII of the GABA B1 $_{1}$ receptor gene (Gabbrl) was achieved in the DRN, four cKO mice and four WT mice were killed and their brains were removed. The midbrain slice (including both the superior and inferior colliculi) was hand-dissected on ice, and then the DRN was dissected by using a $1 \mathrm{~mm}$ diameter punch (Harris Uni-Core-1.00, Ted Pella Inc) from the midbrain slice. The tissue was homogenized in TrisEDTA buffer and digested by proteinase $\mathrm{K}$ to isolate DNA. PCR was conducted to detect the floxed allele and the KO allele, using $40 \mathrm{ng}$ of DNA for each sample. To examine the deletion of the floxed exons VII and VIII, a primer upstream of exon VII (P7) and a primer specific for the loxP site downstream of exon VIII (P8) were used (Haller et al., 2004).

Genotyping to ascertain Cre locus and floxed Gabbr1 locus for the production and maintenance of experimental animals was performed using ear punch samples for PCR with other primer sets (Haller et al., 2004; Iwasato et al., 2004, 2008).

Resident-intruder test and social instigation test before surgery. Each resident male was housed with a female for 3 weeks before starting any behavioral experiment to let them establish territory in the homecage. Then, each resident male was studied for its aggression toward the same intruder (Miczek and O'Donnell, 1978). The female and pups were removed right before the test, and then an intruder was introduced into the homecage of the resident male. Their behavior was recorded for $5 \mathrm{~min}$ after the first bite, or the intruder was removed after $5 \mathrm{~min}$ if no attack occurred. For Experiment 1, eight aggressive encounters, one every other day, were conducted to determine whether the presence or intensity of aggression differed between $\mathrm{cKO}$ and WT mice. For Experiments 3 and 4, aggressive encounters occurred once every other day until the animals showed a stable number of attack bites (variation among the last three encounters $<20 \%$ after $8-16$ encounters), after which cannulation surgery was performed. For Experiments 5 and 7, resident males experienced aggressive encounters six times every other day before surgery to confirm that they showed reliable aggressive behavior. In the rare instances when the intruder started to attack the resident male or the resident did not show any aggressive behavior for three to four consecutive encounters, we replaced the intruder.

The social instigation procedure was implemented as previously described (Fish et al., 1999). Briefly, a sexually mature naive male instigator mouse was placed inside a protective wire mesh cylinder $(8 \mathrm{~cm}$ diameter $\times 10 \mathrm{~cm}$ height), where it could be seen, heard, and smelled by the resident male. The shielded instigator was placed in the middle of the resident's homecage for $10 \mathrm{~min}$. Immediately after removal of the instigator from the resident's homecage, an intruder male was introduced and the 5 min resident-intruder test was conducted. For Experiments 6, 8 , and 9 , all resident males first experienced resident-intruder testing five times every other day. The residents were then characterized in terms of their aggressive behavior with and without social instigation as assessed by conducting twice a resident-intruder test and a social instigation test separated by a $1 \mathrm{~d}$ interval in alternation. All tests were performed during the dark period (6:00-11:00 P.M.) under dim red lights.

Cannulation and drug microinjection test (Experiments 1, 3, and 4). Resident males were anesthetized by intraperitoneal injection of a mixture of $100 \mathrm{mg} / \mathrm{kg}$ ketamine $\mathrm{HCl}$ and $10 \mathrm{mg} / \mathrm{kg}$ xylazine. A 26 gauge guide cannula (Plastics One) was stereotaxically implanted $1.5 \mathrm{~mm}$ above the DRN (AP, $-4.6 \mathrm{~mm}$; ML, $+1.5 \mathrm{~mm}$; DV,$-1.9 \mathrm{~mm}$ to bregma; angled $26^{\circ}$ to the vertical) as calculated from a mouse brain atlas (Franklin and Paxinos, 2008). A 33 gauge obdurator (Plastics One) the same length as the guide cannula was inserted after surgery. The obdurator was moved every other day to prevent blockage and scarring and also to habituate the animals to handling. Animals were housed individually for $5 \mathrm{~d}$ to recover, and then their female and pups were returned into the homecage. One week after the surgery, aggressive behavior was re-established using three resident-intruder tests performed every second day, before starting microinjections.

During drug microinjection, the obdurator was removed and a 33 gauge microinjector (Plastics One) extending $1.5 \mathrm{~mm}$ below the tip of the guide was inserted into the guide cannula to reach the DRN. The microinjector was connected to a $1 \mu \mathrm{l}$ Hamilton syringe placed into an infusion pump (ESP-32; Eicom) via PE 50 tube. The drug was infused in a volume of $0.2 \mu$ l over $2 \mathrm{~min}$, and the microinjector was left in place for $1 \mathrm{~min}$ after the infusion to allow the drug to diffuse completely. Ten minutes after the microinjection, a resident-intruder test was conducted, and the aggressive interactions were recorded for $5 \mathrm{~min}$ after the first attack bite. In Experiment 1, an animal received a total of four microinjections: 0.06 nmol baclofen, $0.3 \mathrm{nmol}$ baclofen, and artificial CSF (aCSF) vehicle twice. In Experiment 3, an animal received a total of four microinjections: $0.1 \mu \mathrm{M} \mathrm{L}$-glutamate, $1 \mu \mathrm{M} \mathrm{L}$-glutamate, and aCSF vehicle twice. The dose of L-glutamate was determined by a pilot study which tested doses from $1 \mu \mathrm{M}$ to $50 \mathrm{~mm}$. In Experiment 4, each animal received a total of four microinjections: $1 \mu \mathrm{M}$ L-glutamate, a combination of $1 \mu \mathrm{M} \mathrm{L}$-glutamate and the mixture of $10 \mu \mathrm{M}$ NBQX plus $50 \mu \mathrm{M}$ APV, and twice vehicle. Drugs were administered in a semi-random order in each experiment.

Drugs. Baclofen $[( \pm)-\beta$-(aminomethyl)-4-chlorobenzenepropanoic acid], L-glutamate, NBQX (NBQX disodium salt), and APV (D-(-)-2amino-5-phosphonovaleric acid) were purchased from Wako Pure Chemical Industries. Drugs were dissolved in either aCSF (Experiments 1-3) or saline (Experiment 4).

\section{In vivo microdialysis}

Extracellular glutamate and GABA in the DRN after baclofen treatment (Experiment 2). In this experiment, we used MI-A-4-01 microdialysis probes (Eicom) which combine a $1 \mathrm{~mm}$ active membrane and a 34 gauge drug microinjector. The tip of the drug microinjector is located right beside the top of the active membrane, thus making it possible to measure the effect of drug application on neurotransmitter release within the DRN. Males were anesthetized with a mixture of ketamine $\mathrm{HCl}(100$ $\mathrm{mg} / \mathrm{kg})$ and xylazine $(10 \mathrm{mg} / \mathrm{kg})$ and were then implanted with a MI-A4-01 probe into the DRN (AP, $-4.6 \mathrm{~mm}$; ML, $+1.5 \mathrm{~mm}$; DV, $-2.4 \mathrm{~mm}$ to bregma; angled $26^{\circ}$ to the vertical) in the morning (10:00-11:00 A.M.). After surgery, animals were placed in the test cage $(19 \times 29 \times 20$ $\mathrm{cm}$ ) with bedding material from the homecage, food, and hydration gel. The probe was perfused with aCSF at a flow rate of $0.5 \mu \mathrm{l} / \mathrm{min}$ using a microsyringe pump (ESP-64; Eicom). Two hours before the beginning of the dark phase (at 4:00 P.M.), the flow rate was increased to $2 \mu \mathrm{l} / \mathrm{min}$ and a $40 \mu \mathrm{l}$ sample was collected every 20 min during the dark period by using a microfraction collector (EF-80, Eicom) cooled with ice. Six samples were collected to measure the baseline level of GABA and glutamate in the DRN. Then, $0.2 \mu \mathrm{laCSF}$ was microinfused into the DRN over $2 \mathrm{~min}$. One hour after the aCSF injection, $0.06 \mathrm{nmol}$ of baclofen was microin- 
jected into the DRN and samples were collected continuously for another $2 \mathrm{~h}$. Microdialysates were stored at $-80^{\circ} \mathrm{C}$ until HPLC analysis.

Extracellular glutamate measurement in the DRN during aggressive behavior and social instigation (Experiments 5 and 6). After resident males were tested for both species-typical aggression without social instigation and social instigation-heightened aggression, they were implanted with a CXG-6 guide cannula (Eicom) aimed just above the DRN (DRN: AP, $-4.6 \mathrm{~mm}$; ML, $+1.5 \mathrm{~mm}$; DV, $-2.4 \mathrm{~mm}$ to bregma; angled $26^{\circ}$ to the vertical) under ketamine-xylazine anesthesia. After surgery, males were housed individually without females, because some females damaged the microdialysis guide cannulae before the test. After 1 week of recovery, resident-intruder encounters were conducted to check whether residents still fought after the surgery. In the morning of the test day, animals were anesthetized with isoflurane and a CX-I-6-01 microdialysis probe (Eicom) with $1 \mathrm{~mm}$ active membrane was inserted into the guide cannula to reach the DRN. Animals were then placed in the test cage $(19 \times 29 \times 20$ $\mathrm{cm}$ ) with bedding material from their homecage. The probe was first perfused with aCSF at a flow rate of $0.5 \mu \mathrm{l} / \mathrm{min}$; at 4:00 P.M. the flow was increased to $2 \mu \mathrm{l} / \mathrm{min}$. After $\sim 2 \mathrm{~h}$ of stabilization, $20 \mu \mathrm{l}$ samples were collected every $10 \mathrm{~min}$ in the dark period. In Experiments 5 and 6, five samples were first collected to measure the baseline level of glutamate in the DRN. Then, in Experiment 5, an intruder male was placed in the test cage for 2 min while the resident male's aggressive behavior was videotaped. In Experiment 6, an instigator in a protective cage was placed in the middle of the test cage for $10 \mathrm{~min}$, and then an intruder male was introduced for a 2 min videotaped encounter. Microdialysate was continuously collected for $1 \mathrm{~h}$ during and after the aggressive encounters, and samples were stored at $-80^{\circ} \mathrm{C}$ until HPLC analysis.

Extracellular 5-HT measurement in the DRN during aggressive behavior and social instigation (Experiments 7 and 8). The test procedure was similar to Experiments 5 and 6, except that the flow rate during sampling was $1 \mu \mathrm{l} / \mathrm{min}$. Every $10 \mathrm{~min}$ the microdialysate sample was immediately injected into the HPLC by an auto injector (EAS-20, Eicom). Five samples were collected to measure the baseline level of 5-HT in the DRN. Then, in Experiment 7, an intruder male was placed in the test cage for $2 \mathrm{~min}$ while the resident male's aggressive behavior was videotaped. In Experiment 8, an instigator in a protective cage was placed in the middle of test cage for $10 \mathrm{~min}$, and then an intruder male was introduced for a 2 min videotaped encounter.

Extracellular 5-HT measurement in the MPFC during aggressive behavior (Experiment 9). After resident males were characterized in terms of their aggressive behavior, they were implanted a CXG-6 guide cannula (Eicom) aimed above the $\mathrm{mPFC}(\mathrm{AP},+2.0 \mathrm{~mm}$; ML,$+0.3 \mathrm{~mm}$; DV, $-0.3 \mathrm{~mm}$ to bregma) under ketamine-xylazine anesthesia. The test procedure was similar to other microdialysis experiments, except that the active membrane of the probe was $2 \mathrm{~mm}$ and the same resident male experienced both species-typical aggression test (without social instigation) and social instigation-heightened aggression test. At the beginning of the dark phase (6:00 P.M.), five samples were collected to measure the baseline level of 5-HT in the mPFC. Then, an intruder male was introduced and stayed for $2 \mathrm{~min}$ in the test cage where the resident male's aggressive behavior was videotaped. Approximately $2 \mathrm{~h}$ later, a caged instigator male was placed in the test cage for $10 \mathrm{~min}$, followed by the introduction of an intruder male for $2 \mathrm{~min}$ with videotaping.

HPLC analysis. Microdialysate samples were assayed using a HPLC system equipped with an electrochemical detector (ECD-300, Eicom) and ODS columns: EICOMPAK SC-50DS $(3.0 \mathrm{~mm}$ ID $\times 150 \mathrm{~mm}$, Eicom) at $30^{\circ} \mathrm{C}$ for GABA and glutamate, and EICOMPAC PP-ODS II (4.6 $\mathrm{mm}$ ID $\times 30 \mathrm{~mm}$, Eicom) at $25^{\circ} \mathrm{C}$ for 5 -HT. To measure GABA and glutamate, dialysates were derivatized with one-third volume of orthophthalaldehyde-2-mercaptoethanol (OPA-2ME; containing $4 \mathrm{~mm}$ ortho-phtalaldehyde, $0.2 \%$ 2-mercaptoethanol, $100 \mathrm{~mm}$ potassium carbonate, and 10\% ethanol) for $2.5 \mathrm{~min}$. Different mobile phases were used to measure GABA and glutamate: $25 \mathrm{~mm}$ PBS, $\mathrm{pH} 2.8,13.4 \mu \mathrm{M}$ EDTA$2 \mathrm{Na}$ and $50 \%$ methanol for GABA, and $70 \mathrm{~mm}$ PBS, pH 6, $13.4 \mu \mathrm{M}$ EDTA-2Na and 30\% methanol for glutamate. In Experiment 2, each microdialysate sample was split into two to measure both GABA $(24 \mu \mathrm{l})$ and glutamate $(9 \mu \mathrm{l})$ concentrations. For the analysis of glutamate release during aggressive behavior (Experiments 5 and 6), $18 \mu \mathrm{l}$ of microdialy- sate sample was used for glutamate measurement. To measure 5-HT (Experiments 7-9), a mobile phase with $100 \mathrm{~mm}$ PBS, pH 5.4, $500 \mathrm{mg} / \mathrm{L}$ SDS, $13.4 \mu \mathrm{M}$ EDTA-2Na, and $2 \%$ methanol was used, and the whole 10 min microdialysate samples $(10 \mu \mathrm{l})$ were injected automatically. The changes in the GABA, glutamate, and 5-HT concentrations were expressed as the percentage change from the average baseline samples for each individual.

Statistics. Detailed behavioral analysis of the videotaped residentintruder tests was conducted by a trained observer to quantify aggressive behaviors (i.e., attack bites, sideways threats, pursuits, tail rattles) and nonaggressive behaviors (i.e., walking, rearing, auto-grooming, contacts; Grant and Mackintosh, 1963; Miczek and O'Donnell, 1978). The occurrence of these behaviors was recorded by using free software established by A. Tanave (TanaMove0.07). The frequency of attack bites and the duration of all other operationally defined behaviors were analyzed.

For Experiment 1, repeated-measures two-way ANOVA was conducted to examine the effect of genotype and session on attack bites before the surgery (WT: $n=17, \mathrm{cKO}: n=19$ ). To examine the effect of baclofen, repeated-measures two-way ANOVA was performed to examine the effect of genotype and drug treatment on aggressive and nonaggressive behaviors in WT $(n=11)$ and 5-HTT-GABA ${ }_{\mathrm{B} 1}{ }^{-1-} \mathrm{cKO}$ mice $(n=12)$, and Tukey-Kramer post hoc test was used $(\alpha=0.05)$. In this experiment, there were four missing data values, two data points (1 WT and $1 \mathrm{cKO}$ ) for $0.06 \mathrm{nmol}$ baclofen and two data values (1 WT and 1 cKO) for $0.3 \mathrm{nmol}$ baclofen. Those values were substituted with the average value of each genotype for the corresponding dose for statistical analysis, and the degrees of freedom were adjusted. For Experiments 3 and 4, repeated-measures one-way ANOVA was performed to examine the effect of the intra-DRN microinjection of L-glutamate and L-glutamate with APV + NBQX on aggressive and nonaggressive behaviors. Tukey-Kramer test was conducted as a post hoc analysis to determine which doses of the drug differed significantly from vehicle $(\alpha=0.05)$.

For the in vivo microdialysis, repeated-measures one-way ANOVA was performed for all data; 15 data values for Experiment 2 (6 base line samples, three samples after the aCSF microinfusion, and 6 samples after the baclofen microinfusion), 11 data values for Experiments 5, 7, and 9 ( 5 base line samples, and 6 samples during and after aggressive encounter), and 12 data values for Experiments 6, 8, and 9 (5 base line samples, one social instigation, and 6 samples during and after aggressive encounter). If the $F$ value was significant, Tukey-Kramer post hoc tests (Experiment 2) or $t$ tests with Bonferroni correction (Experiments 6-9) were conducted to compare an average baseline value to each subsequent sample $(\alpha=$ $0.05)$.

\section{Results \\ Baclofen acts at $\mathrm{GABA}_{\mathrm{B}}$ receptors on non-5-HT neurons to escalate aggression}

We first examined the role of $\mathrm{GABA}_{\mathrm{B}}$ receptors on 5-HT neurons in relation to escalated aggressive behavior by using a $5-\mathrm{HT}$ neuron-specific $\mathrm{GABA}_{\mathrm{B}}$ receptor cKO mouse. The $\mathrm{cKO}$ mice were generated by crossing a floxed $\mathrm{GABA}_{\mathrm{B} 1}$ mouse with a 5-HTT-Cre (Tg208) mouse. To examine the expression pattern of Cre protein in the midbrain of 5-HTT-Cre mouse, we crossed 5-HTT-Cre mouse to RNZ reporter mice, which express $\beta$-galactsidase ( $\beta$-Gal) in Cre-positive cells. Immunostaining of Tph and $\beta$-Gal showed that $95.6 \%$ of Cre-positive neurons were 5 -HT neurons in the midbrain area (both Tph and $\beta$-Gal-positive: 1341 cells, Tph only: 82 cells, $\beta$-Gal only: 62 cells; Fig. $1 A-F)$. Although the Cre is also expressed in the thalamic sensory relay nuclei in 5-HTT-Cre mice (Arakawa et al., 2014; Suzuki et al., 2015), our current data showed that Cre protein was preferentially expressed on the 5-HT neurons in the case of midbrain area where baclofen was locally administered. A 5-HTT-Cre mouse was then crossed with a floxed $\mathrm{GABA}_{\mathrm{B} 1}$ mouse to obtain 5-HT neuron-specific $\mathrm{GABA}_{\mathrm{B}}$ receptor $\mathrm{CKO}$ mice. PCR analysis showed that the tissue punch of the $\mathrm{DRN}$ area in the $\mathrm{CKO}$ mice showed both knock-out allele and WT allele, whereas the other 

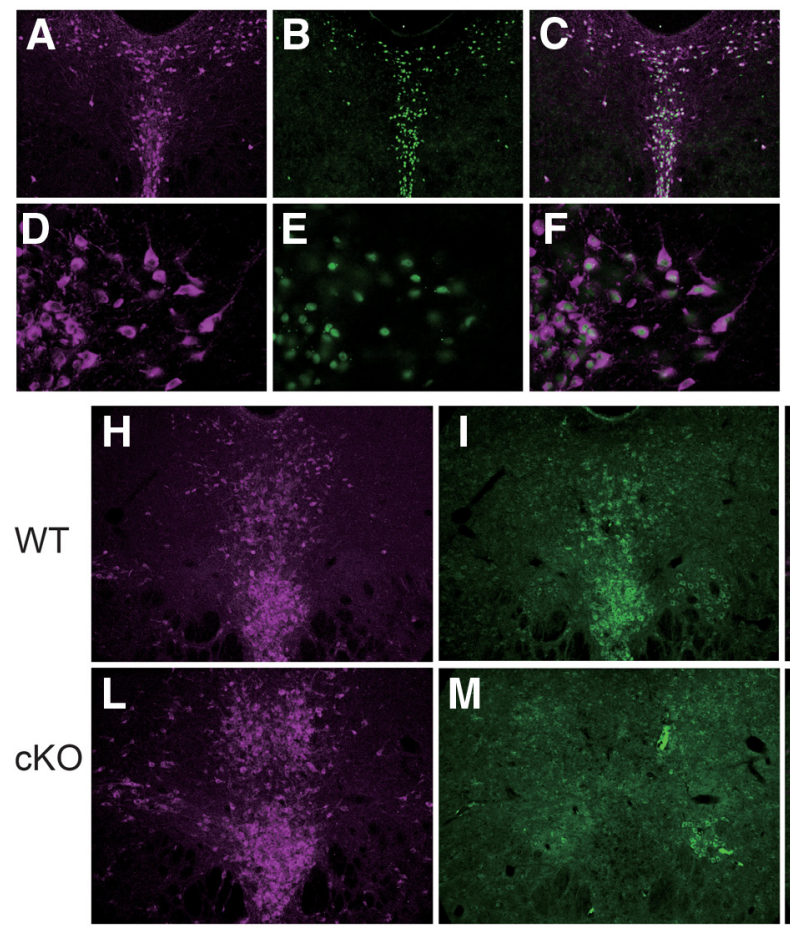

$\mathbf{P}$

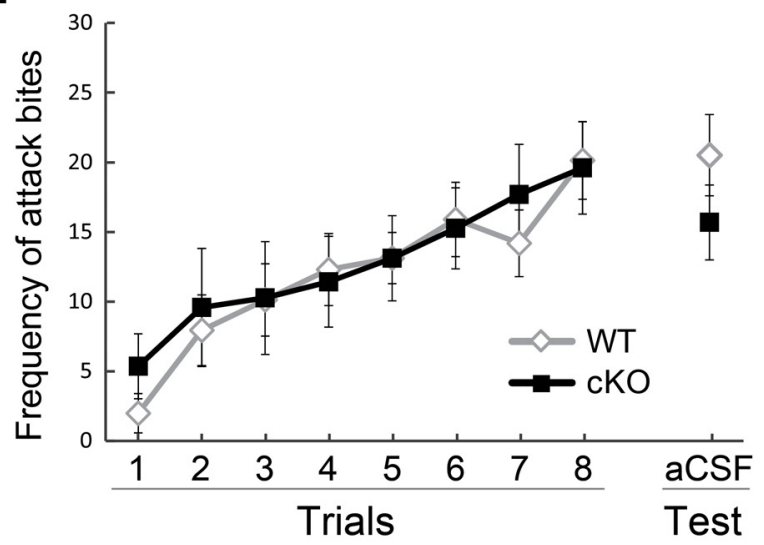

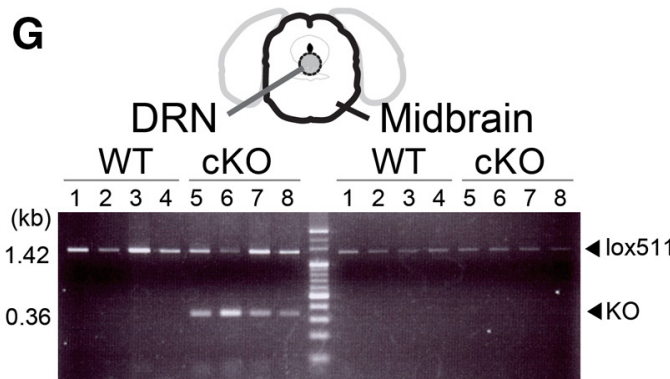
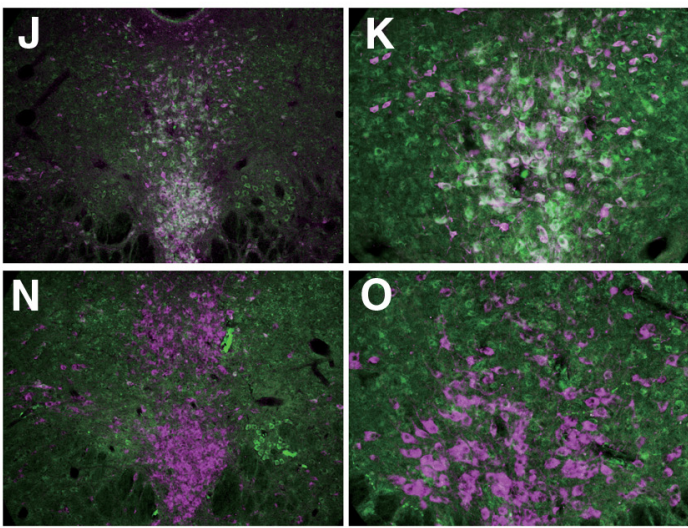

Q

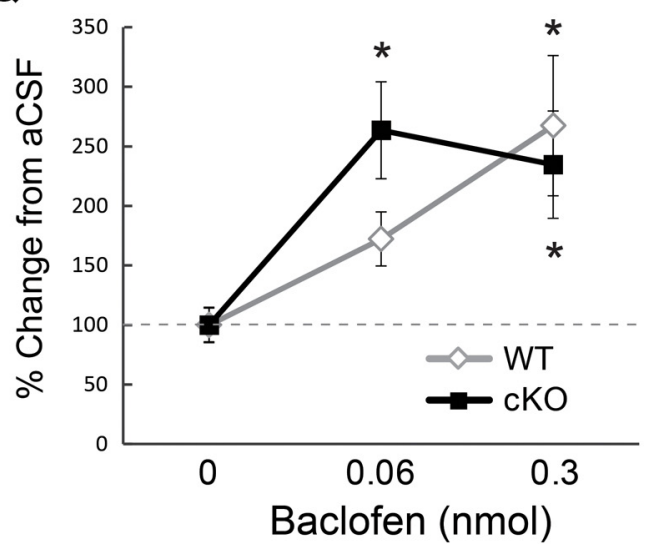

Figure 1. Escalated aggression induced by intra-DRN baclofen in the conditional knock-out mouse of GABA $\mathrm{B}_{\mathrm{B}}$ receptor on 5-HT neurons. 5-HTT-Cre mouse expresses Cre protein in Tph-positive 5 -HT raphe neurons in the midbrain $(\boldsymbol{A}-\boldsymbol{F})$. Immunostaining of Tph ( $\boldsymbol{A}, \boldsymbol{D}$; Sigma-Aldrich, anti-Tph 1:1000) and $\beta$-gal ( $\boldsymbol{B}, \boldsymbol{E}$; Millipore, anti- $\beta$-gal 1:1000), and colocalization of Tph and $\beta$-gal $(\boldsymbol{C}, \boldsymbol{F})$ in the DRN of 5-HTT-Cre mice crossed with RNZ reporter mice with $10 \times(\boldsymbol{A}-\boldsymbol{C})$ and $40 \times(\boldsymbol{D}-\boldsymbol{F})$ magnification. $\mathbf{G}, \mathrm{PCR}$ analysis showed that 5 -HT neuron-specific GABA ${ }_{B}$ receptor $\mathrm{CKO}$ mice $(n=4)$ possessed $\mathrm{K} 0$ allele as well as floxed allele (lox511) in the DRN puncture, whereas only floxed allele was detected in midbrain leftover sample. WT mice $(n=4)$ showed only floxed allele in both DRN and midbrain sample. Immunohistochemistry confirmed the deletion of $\mathrm{GABA}_{\mathrm{B}}$ receptor expression on Tph-positive 5-HT neurons in cK0 mice $(\boldsymbol{L}-\mathbf{0})$ in comparison with WT mice $(\boldsymbol{H}-\boldsymbol{K})$.

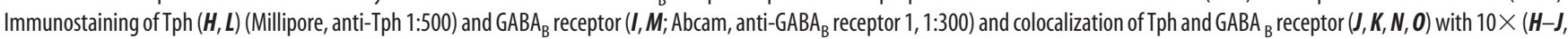
$\boldsymbol{L}-\boldsymbol{N})$ and $20 \times(\boldsymbol{K}, \mathbf{0})$ magnification. $\boldsymbol{P}$, Frequency of attack bites in cKO and its WT littermate did not differ before the surgery and at the vehicle injection into the DRN. $\mathbf{Q}$, Effect of intra-DRN baclofen on attack bites behavior in CKO and WT littermate. Both cKO and WT littermate showed significant increase of attack bites by $0.3 \mathrm{nmol}$ baclofen from its aCSF level, whereas $0.06 \mathrm{nmol}$ baclofen significantly increased attack bites only in cKO mice. Data are mean \pm SEM expressed as percentage change from vehicle; ${ }^{*} p<0.05$ compared with its vehicle control within the genotype.

midbrain area had only the WT allele (Fig. $1 G$ ). Immunostaining for Tph and $G_{A B A}$ showed a strong expression of $G_{B A B}$ receptors on Tph-positive DRN neurons in the WT (Fig. $1 H-K$ ), but $\mathrm{cKO}$ mice rarely express $\mathrm{GABA}_{\mathrm{B}}$ receptor on Tph-positive neurons (Fig. $1 L-O$ ).

Before the cannulation surgery, the level of aggressive behavior in the cKO mice was comparable to that of WT littermates (Fig. 1P). Repeated-measures two-way ANOVA showed that there was no main effect of genotype on aggressive behavior over eight encounters. After cannulation, we examined their aggression after microinjecting either baclofen $(0.06$ or $0.3 \mathrm{nmol})$ or aCSF into the DRN. Repeated-measures two-way ANOVA showed that there were significant main effects of baclofen on all aggressive behaviors including attack bites $\left(F_{(2,42)}=12.646, p<\right.$ $0.0001)$, sideways threats $\left(F_{(2,42)}=11.333, p=0.0001\right)$, tail rattles $\left(F_{(2,42)}=9.380, p=0.0004\right)$, and pursuits $\left(F_{(2,42)}=7.293\right.$, $p=0.0019)$, and baclofen increased these behaviors in a dosedependent manner (Fig. 1Q; Table 2). There was neither a significant main effect of genotype nor any genotype $\times$ drug interaction on any aggressive or nonaggressive behaviors. However, post hoc $t$ tests showed that when cKO mice were treated with $0.06 \mathrm{nmol}$ baclofen they showed a significant increase in attack bites compared with their basal level, whereas WT mice showed a smaller, nonsignificant increase at this dose (Fig. 1I). The higher dose $(0.3 \mathrm{nmol})$ caused significant increases in attack bite frequency in both groups. Repeated-measures two-way 


\begin{tabular}{|c|c|c|c|}
\hline & $\mathrm{aCSF}$ & Baclofen $0.06 \mathrm{nmol}$ & Baclofen $0.3 \mathrm{nmol}$ \\
\hline \multicolumn{4}{|c|}{ Attack bites } \\
\hline WT & $20.5 \pm 2.9$ & $32.9 \pm 3.6$ & $43.9 \pm 7.3^{*}$ \\
\hline cKO & $15.7 \pm 2.7$ & $41.2 \pm 7.9^{*}$ & $34.5 \pm 6.5^{*}$ \\
\hline \multicolumn{4}{|c|}{ Sideways threats (s) } \\
\hline WT & $12.0 \pm 1.8$ & $23.8 \pm 3.5^{*}$ & $24.8 \pm 5.8^{*}$ \\
\hline cKO & $8.8 \pm 2.0$ & $28.8 \pm 6.5^{*}$ & $21.6 \pm 5.8$ \\
\hline \multicolumn{4}{|c|}{ Tail rattles (s) } \\
\hline WT & $18.0 \pm 3.7$ & $33.1 \pm 7.3$ & $37.6 \pm 9.0$ \\
\hline cKO & $11.8 \pm 3.4$ & $27.2 \pm 6.6^{*}$ & $32.9 \pm 7.4^{*}$ \\
\hline \multicolumn{4}{|c|}{ Pursuits (s) } \\
\hline WT & $6.7 \pm 2.6$ & $10.3 \pm 2.9$ & $26.6 \pm 9.7^{*}$ \\
\hline cKO & $4.7 \pm 2.3$ & $15.2 \pm 5.1$ & $15.9 \pm 4.8$ \\
\hline \multicolumn{4}{|c|}{ Walking (s) } \\
\hline WT & $73.5 \pm 5.5$ & $74.9 \pm 7.8$ & $113.1 \pm 19.9$ \\
\hline cKO & $80.5 \pm 5.7$ & $72.0 \pm 6.6$ & $125.5 \pm 21.9$ \\
\hline \multicolumn{4}{|c|}{ Rearing (s) } \\
\hline WT & $16.3 \pm 3.3$ & $11.5 \pm 3.3$ & $7.3 \pm 2.3$ \\
\hline cKO & $19.8 \pm 3.9$ & $13.1 \pm 4.1$ & $9.1 \pm 3.0$ \\
\hline \multicolumn{4}{|c|}{ Self-grooming (s) } \\
\hline WT & $29.2 \pm 8.7$ & $28.2 \pm 4.9$ & $14.1 \pm 4.8$ \\
\hline cKO & $32.2 \pm 7.5$ & $23.5 \pm 4.7$ & $12.8 \pm 3.9^{*}$ \\
\hline \multicolumn{4}{|c|}{ Social contact (s) } \\
\hline WT & $22.0 \pm 8.5$ & $15.9 \pm 3.9$ & $20.3 \pm 7.5$ \\
\hline cKO & $18.2 \pm 4.8$ & $14.3 \pm 3.6$ & $20.4 \pm 4.8$ \\
\hline
\end{tabular}

All values are mean \pm SEM; ${ }^{*} p<0.05$ compared with aCSF.

ANOVAs also found significant main effects of baclofen on some nonaggressive behaviors including walking $\left(F_{(2,42)}=10.686, p=\right.$ $0.0002)$, rearing $\left(F_{(2,42)}=6.060, p=0.0049\right)$, and grooming $\left(F_{(2,42)}=5.312, p=0.0088\right)$. The highest dose of baclofen $(0.3$ $\mathrm{nmol})$ significantly increased walking and reduced rearing and grooming (Table 2) due to the induction of stereotypic turning as a side effect. To summarize, the deletion of $\mathrm{GABA}_{\mathrm{B}}$ receptors in 5 -HT neurons had no effect on the aggression-heightening effects of intra-DRN baclofen. Rather, cKO mice showed slightly higher sensitivity to the proaggressive effect of baclofen than WT mice. We conclude that the site of action for baclofen's escalation of aggressive behavior must be the $\mathrm{GABA}_{\mathrm{B}}$ receptors on nonserotonergic neurons. Our previous studies showed a significant increase in aggressive behavior by intra-DRN administration of baclofen in ICR/Jcl strain (Takahashi et al., 2010b, 2012), and current study replicated the aggression-heightening effect of baclofen in a C57BL/6J background strain. However, the effective dose seems to differ between strains. ICR/Jcl showed a significant increase of attack bites with a moderate dose of baclofen $(0.06 \mathrm{nmol})$, whereas a higher dose $(0.3 \mathrm{nmol})$ was required for $\mathrm{C} 57 \mathrm{BL} / 6 \mathrm{~J}$ mice.

\section{Baclofen increases glutamate, but not GABA, release in the DRN}

In the DRN, $\mathrm{GABA}_{\mathrm{B}}$ receptors are localized on GABA interneurons and also the terminals of glutamatergic projections (Bagdy et al., 2000; Soiza-Reilly et al., 2013). If baclofen acts on these presynaptic or interneuronal $\mathrm{GABA}_{\mathrm{B}}$ receptors in the DRN, we can predict that the release of GABA and/or glutamate will be reduced by baclofen administration. To examine the effect of an aggression-heightening dose of baclofen (0.06 nmol for ICR strain; Takahashi et al., 2010b, 2012) on the synaptic release of GABA and glutamate within the DRN, we measured extracellular GABA and glutamate concentrations in the DRN using in vivo microdialysis. Microinjection of $0.06 \mathrm{nmol}$ baclofen into the DRN did not change GABA release in the DRN (Fig. 2A). In contrast, we found that baclofen significantly increased the level of extracellular glutamate $\left(F_{(14,112)}=2.687, p=0.0020\right.$; Fig. $\left.2 B\right)$. A significant increase in glutamate was observed in the first 20 min sample, after which the level of glutamate returned to its basal level. There was no effect of aCSF injection on either glutamate or GABA release in the DRN (Fig. $2 A, B$ ). At present, it is unknown how exactly this unexpected increase in glutamate as a result of intraDRN baclofen was achieved. Nonetheless, we interpret the increase of glutamate in the DRN in conjunction with our microinjection data as being relevant to baclofen-heightened aggression.

\section{Direct injection of L-glutamate into the DRN enhances aggressive behavior}

Next, we asked whether the increase of glutamate input in the DRN plays any role in the aggressive behavior of male mice. Thus, we examined the effect of direct injection of L-glutamate into the DRN on aggressive behavior. Either L-glutamate $(0.1 \mu \mathrm{M}$ or 1.0 $\mu \mathrm{M})$ or aCSF was microinjected into the DRN of ICR resident male mice and their aggressive behavior was examined $10 \mathrm{~min}$ after the injection. We found that L-glutamate significantly increased attack bites in a dose-dependent manner $\left(F_{(2,18)}=4.609\right.$, $p=0.0242$ ), and post hoc tests showed a significant increase in attack bites after microinjecting $1.0 \mu \mathrm{M}$ glutamate into the DRN (Fig. 3A). L-glutamate also had a significant effect on tail-rattle behavior $\left(F_{(2,18)}=3.768, p=0.0429\right)$, and $0.1 \mu \mathrm{M} \mathrm{L}$-glutamate significantly reduced tail rattles (Table 3 ). L-glutamate tended to dose-dependently increase other aggressive behaviors (sideways threats and pursuits), but these effects did not reach statistical significance. L-glutamate had no effect on nonaggressive behaviors, such as walking or rearing (Table 3). Preliminary data showed that the higher concentration of glutamate $(100 \mu \mathrm{M}$ or 10 $\mathrm{mm}$ ) did not increase attack bites (data not shown); thus, glutamate in the DRN produced an inverted U-shape dose-effect relationship with regard to attack bites.

To examine the involvement of ionotropic glutamate receptors on this aggression-heightening effect of L-glutamate, the antagonist mixture (APV+NBQX) was coinjected with $1.0 \mu \mathrm{M}$ L-glutamate into the DRN of male mice (Fig. $3 B$ ). Repeated measures one-way ANOVA showed a significant main effect of drug on attack bites $\left(F_{(2,20)}=5.751, p=0.0106\right)$, sideways threat $\left(F_{(2,20)}=4.846, p=0.0192\right)$, tail rattles $\left(F_{(2,20)}=4.846, p=\right.$ $0.0192)$, as well as walking $\left(F_{(2,20)}=3.923, p=0.0365\right)$. Post hoc tests showed that microinjection of L-glutamate significantly increased aggressive behaviors including attack bites, sideways threat, and tail rattles compared with saline control. Coinjection of APV+NBQX with L-glutamate did not significantly increase any aggressive behaviors from vehicle, and there were significant reductions of attack bites and sideways threat in coinjection group compared with L-glutamate group (Fig. 3B; Table 4). Therefore, antagonism of ionotropic glutamate receptors blocked the aggression-heightening effect of L-glutamate.

\section{Increased glutamate input in the DRN during aggressive encounter and further increase during escalated aggression}

To examine whether the increase in glutamate input within the DRN occurs during aggressive behavior in the absence of pharmacological intervention, we measured the extracellular glutamate level in the DRN while animals were engaging in aggressive behavior (Fig. 4A, top). We found that the level of extracellular glutamate in the DRN increased during the aggressive encounter $\left(F_{(10,100)}=2.057, p=0.0351\right)$, and post hoc tests identified a significant increase in glutamate in the first 10 min sample (Fig. $4 B$ ). To determine whether or not increased physical activity during the 
aggressive encounter caused the increased glutamate input in the DRN, we examined the correlation between locomotor activity and extracellular glutamate in the DRN during six baseline samples. Our preliminary data showed that there was no correlation between extracellular glutamate and locomotor activity $\left(n=2, r^{2}=0.14\right.$ and $r^{2}=$ 0.04 each). Therefore, the increase of glutamate release in the DRN was induced specifically by aggressive behavior.

To examine whether or not the escalation of aggressive behavior corresponds to further increases of glutamate input in the DRN, we examined the level of extracellular glutamate during heightened aggression induced by social instigation, a behavioral procedure to provoke aggressive behavior of male rodents (Fish et al., 1999; Fig. 4A, bottom). Test animals were examined for their aggression with and without social instigation, and we confirmed that the social instigation procedure significantly increased the frequency of attack bites compared with aggressive encounters without social instigation before the surgery $\left(t_{(33)}=-7.404, p<\right.$ 0.0001 ; Fig. $4 C$ ), and during in vivo microdialysis $\left(t_{(46)}=2.692, p=0.0099\right.$; Fig. $4 D)$. Repeated-measures one-way ANOVA showed that there was a significant change in extracellular glutamate in the DRN $\left(F_{(9,99)}=9.168, p<0.0001\right)$, and significant increases of glutamate were observed both during the social instigation and for $20 \mathrm{~min}$ after the aggressive encounter (Fig. 4E). Glutamate tended to remain elevated for up to $1 \mathrm{~h}$ after the aggressive encounter, but after 20 min the differences were no longer statistically significant. The increase in glutamate levels during aggressive behavior tended to be higher in instigationheightened aggression (166\%) compared with that of speciestypical aggression (143\%), so glutamate levels were positively correlated with the level of aggression.

\section{5-HT release in the DRN and mPFC increased during escalated, but not during species-typical, aggression}

Because excitatory glutamate input was increased in the DRN of resident male mice during aggressive behavior, it is possible that the 5-HT release in the DRN and in its projection areas was increased by this glutamate input. Thus, we examined the 5-HT release in the DRN during aggressive encounters of resident male mice. There was no significant main effect of sample time on extracellular 5-HT in the DRN, and we did not observe any change in 5-HT levels during the first $10 \mathrm{~min}$ sampling period that included the 2 min aggressive encounter (Fig. 5A). We then examined the 5-HT release in the DRN during social instigation and instigation-heightened aggression (Fig. 5B) and found a significant main effect of sample time on extracellular 5-HT in the DRN $\left(F_{(11,121)}=7.318, p<0.0001\right)$. There were significant increases of 5 -HT release in the DRN both during 10 min of social instigation and also during the subsequent escalated aggression.
To examine the change of 5-HT release in one of the projection sites, we then inserted a $2 \mathrm{~mm}$ microdialysis membrane probe into the mPFC. We first examined the 5-HT release during species-typical aggression (without instigation), and again there was no main effect of sample time on extracellular 5-HT concentration in the mPFC (Fig. 5C). By contrast, when we measured 5-HT release during social instigation and subsequent instigation-heightened aggression, we observed a significant main effect of sample time on 5 -HT in the $\operatorname{mPFC}\left(F_{(7,77)}=4.076\right.$, $p=0.0001$; Fig. 5D). There were trends toward increases in 5-HT during the social instigation period, and during and after the instigation-heightened aggression but the increases did not reach statistical significance due to large variance.

\section{Discussion}

Glutamate is an important mediator of baclofen-heightened aggression in the DRN

Previously, we showed that microinjection of the $\mathrm{GABA}_{\mathrm{B}}$ receptor agonist baclofen into the DRN escalated aggression in male mice, both quantitatively and qualitatively (Takahashi et al., 2010b, 2012). Because this effect of baclofen depends on the activation of 5-HT neurons in the DRN (Takahashi et al., 2010b), we hypothesized that the aggression-heightening effect of baclofen was mediated by $\mathrm{GABA}_{\mathrm{B}}$ receptors on nonserotonergic neurons. In this study, we demonstrated that genetic deletion of $\mathrm{GABA}_{\mathrm{B}}$ receptors in 5-HT neurons did not affect the aggression-heightening effect of intra- 
A

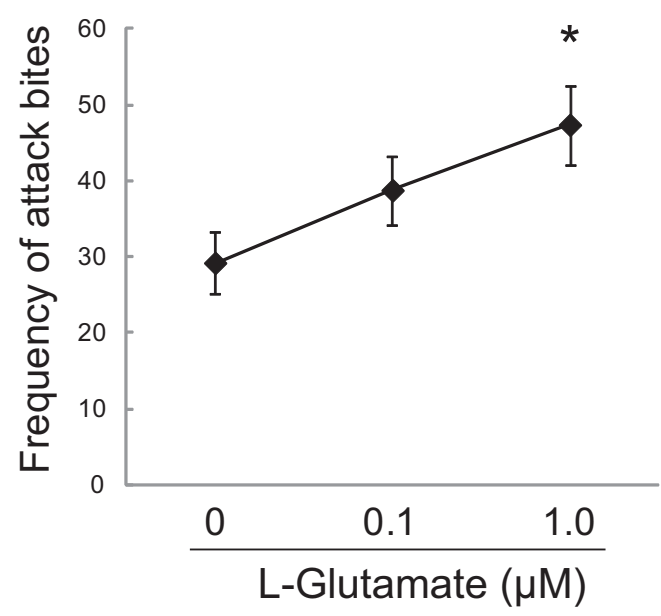

B

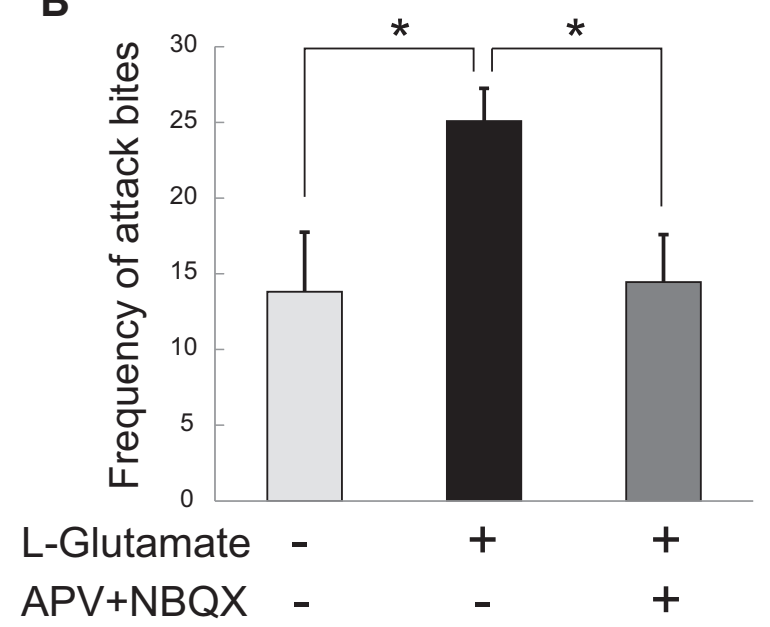

Figure 3. Increase of glutamate in the DRN causes escalation of attack bites of male mice. $A$, Microinjection of L-glutamate into the DRN enhanced the frequency of attack bites with dose-dependent manner. Values are mean $\pm \mathrm{SEM} ;{ }^{*} p<0.05$ compared with vehicle control. $\boldsymbol{B}$, Coadministration of a mixture of AMPA receptor antagonist NBQX (10 $\mu \mathrm{M}$ ) and NMDA receptor antagonist APV $(50 \mu \mathrm{m})$ blocked the effect of L-glutamate $(1 \mu \mathrm{m})$ on frequency of attack bites. L-glutamate itself significantly increased the frequency of attack bites compared with vehicle, whereas L-glutamate did not increase attack bites from its vehicle level when it is coadministered with the antagonist mixture. Values are mean $\pm S E M ;{ }^{*} p<0.05$.

Table 3. Effect of intra-DRN glutamate on aggressive and nonaggressive behaviors

\begin{tabular}{lccc}
\hline & \multicolumn{3}{l}{ Glutamate $(\mu \mathrm{M})$} \\
\cline { 2 - 4 } & 0 & 0.1 & 1 \\
\hline Attack bites & $29.3 \pm 4.1$ & $38.8 \pm 4.5$ & $47.4 \pm 5.2^{*}$ \\
Sideways threats (s) & $32.4 \pm 4.0$ & $40.2 \pm 5.0$ & $42.6 \pm 4.8$ \\
Tail rattles (s) & $25.1 \pm 3.2$ & $14.7 \pm 2.0^{*}$ & $38.6 \pm 10.5$ \\
Pursuits (s) & $0.3 \pm 0.1$ & $0.5 \pm 0.3$ & $0.9 \pm 0.4$ \\
Walking (s) & $62.4 \pm 5.4$ & $54.2 \pm 4.1$ & $57.0 \pm 3.1$ \\
Rearing (s) & $62.3 \pm 9.2$ & $47.4 \pm 9.8$ & $57.2 \pm 10.1$ \\
Self-grooming (s) & $29.4 \pm 6.6$ & $27.5 \pm 6.1$ & $25.0 \pm 4.4$ \\
Social contact (s) & $24.2 \pm 3.4$ & $27.0 \pm 5.2$ & $20.5 \pm 2.3$ \\
\hline
\end{tabular}

Two doses of $\mathrm{L}$-glutamate were examined. All values are mean \pm SEM. ${ }^{*} p<0.05$ compared with vehicle.

Table 4. The effect of $1 \mu \mathrm{M} \mathrm{L}$-glutamate was antagonized by coadministration of $50 \mu \mathrm{M}$ APV $+10 \mu \mathrm{M}$ NBQX

\begin{tabular}{|c|c|c|c|}
\hline & 0 & Glutamate & Glutamate \\
\hline & 0 & 0 & $A P V+N B Q X$ \\
\hline Attack bites & $13.8 \pm 3.9$ & $25.1 \pm 2.2^{*}$ & $14.5 \pm 3.1^{* *}$ \\
\hline Sideways threats (s) & $19.0 \pm 4.0$ & $33.8 \pm 3.7^{*}$ & $20.9 \pm 4.0^{* *}$ \\
\hline Tail rattles (s) & $6.9 \pm 1.7$ & $18.2 \pm 3.4^{*}$ & $12.3 \pm 2.3$ \\
\hline Pursuits (s) & $0.0 \pm 0.0$ & $0.0 \pm 0.0$ & $0.0 \pm 0.0$ \\
\hline Walking (s) & $46.4 \pm 7.0$ & $45.6 \pm 5.6$ & $34.2 \pm 4.1$ \\
\hline Rearing (s) & $58.7 \pm 10.1$ & $57.3 \pm 10.1$ & $42.0 \pm 8.7$ \\
\hline Self-grooming (s) & $13.7 \pm 2.7$ & $24.0 \pm 4.1$ & $25.7 \pm 6.2$ \\
\hline Social contact (s) & $26.2 \pm 3.8$ & $27.1 \pm 8.0$ & $26.6 \pm 6.2$ \\
\hline
\end{tabular}

All values are mean \pm SEM. ${ }^{*} p<0.05$ compared with vehicle, ${ }^{* *} p<0.05$ compared with L-glutamate group in antagonists coinjection group.

DRN baclofen in male cKO mice, providing further evidence of the important role of $\mathrm{GABA}_{\mathrm{B}}$ receptor modulation of nonserotonergic neurons in baclofen-heightened aggression. Higher sensitivity to the proaggressive effect of baclofen in cKO mice indicates that $\mathrm{GABA}_{\mathrm{B}}$ receptors on 5-HT neurons have an inhibitory role on aggressive behavior.

In addition to 5-HT neurons, almost all GABAergic neurons, as well as other types of neurons, such as glutamatergic neurons, in the DRN express GABA $_{B}$ receptors (Serrats et al., 2003; SoizaReilly et al., 2013). In vitro experiments using rat midbrain slices have shown that the application of baclofen inhibits glutamate release and hyperpolarizes 5-HT neurons (Colmers and Williams, 1988; Soiza-Reilly et al., 2013). On the other hand, in the ventral tegmental area, lower concentrations of baclofen inhibit GABA neurons and consequently disinhibit the postsynaptic dopamine neurons, whereas higher doses directly inhibit the dopamine neurons (Cruz et al., 2004; Labouèbe et al., 2007). Because we previously found that an aggression-heightening dose of baclofen microinjected into the DRN increased the release of 5-HT in the mPFC (Takahashi et al., 2010b), we originally hypothesized that this dose of baclofen preferentially acts on GABA interneurons and thus reduces GABA input in the DRN which therefore disinhibits 5-HT neuronal activity. Unexpectedly, our results showed that an aggression-heightening dose of baclofen increased the glutamate release in the DRN, but did not change the level of GABA. At present, we do not have an explanation as to how baclofen could increase extracellular glutamate in the DRN. One possibility is that baclofen preferentially inhibits some GABA interneurons that modulate glutamatergic terminals, but this reduction of GABA release was minor compared with net GABA tone in the DRN, and thus we could not detect this change using in vivo microdialysis. Another possibility could be the involvement of glial $\mathrm{GABA}_{\mathrm{B}}$ receptors, because it has been shown that baclofen increases $\mathrm{Ca}^{2+}$ influx of glia in vitro (Meier et al., 2008), and thus it may be possible to increase glutamate release from glial cells (Nedergaard et al., 2002). Analysis of data from conditional knock-out mice that lack $\mathrm{GABA}_{\mathrm{B}}$ receptors on either GABA interneurons or glial cells may allow us to identify the sites of action for baclofen to escalate aggression. Still, our results conflict with in vitro brain slice studies that showed a reduction of glutamate release by baclofen application. It is possible that macro circuits of several brain areas, which could not be examined in dissected brain slices, are involved in this in vivo phenomenon. Although the exact site of action for baclofen has to be clarified in future experiments, our results indicated that the increase of glutamate input into the DRN caused the escalation of aggression in male mice.

\section{Glutamate input in the DRN controls aggressive behavior of male mice}

This study is the first in vivo microdialysis study to show a change in glutamate input in the DRN during aggressive behavior in male mice. We detected a link between the level of glutamate 

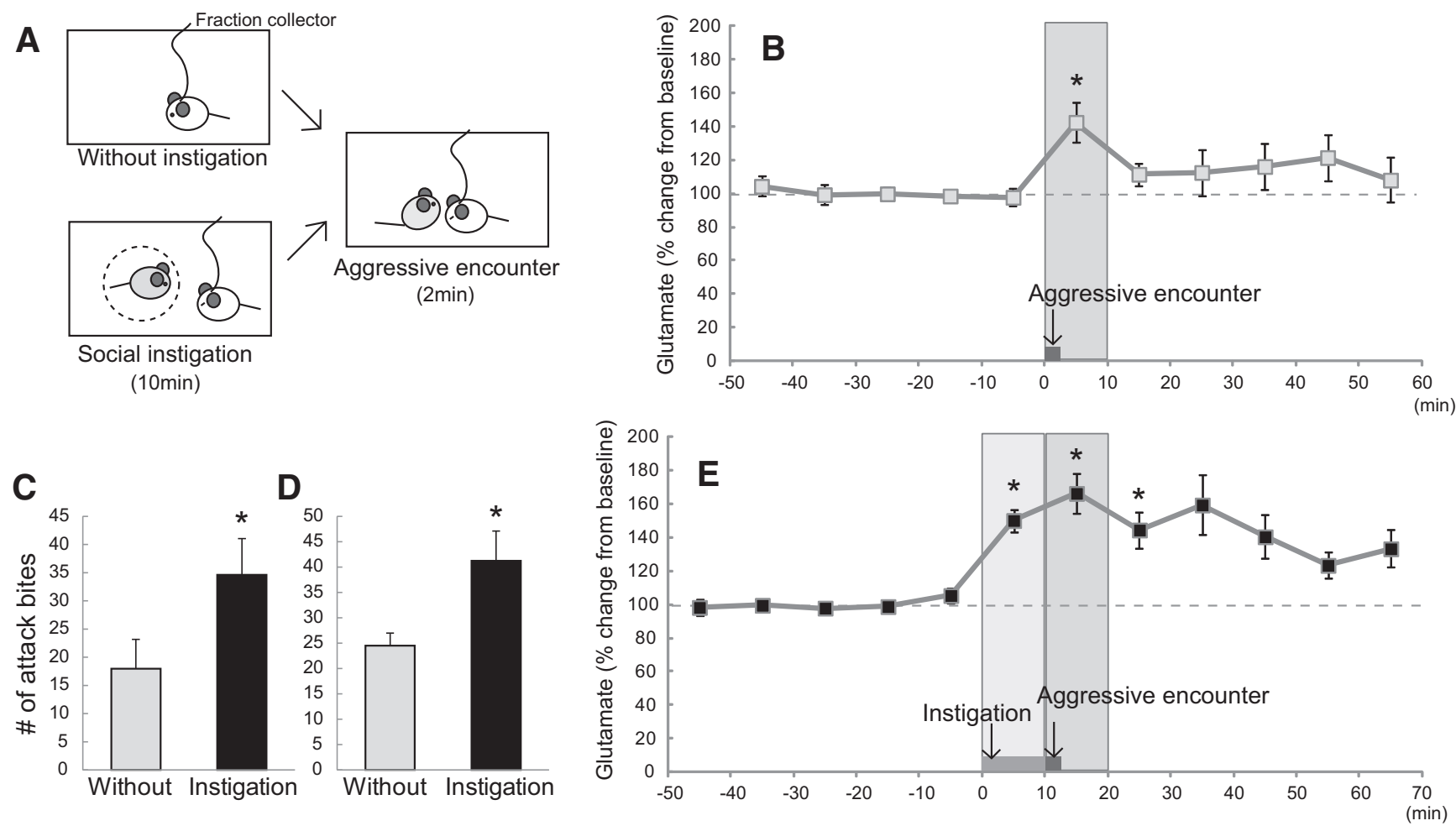

Figure 4. Glutamate release in the DRN evoked by aggressive encounter and instigation-heightened aggression. $A$, Schematics of the experiments. Top, Species-typical aggression (without instigation) group experienced only 2 min aggressive encounter with an intruder. Bottom, In social instigation group, a caged-instigator was introduced into the test cage of resident male for 10 min, and then an intruder male was introduced and stayed for $2 \mathrm{~min}$. $\boldsymbol{B}$, Aggressive encounter without instigation increased the glutamate level in the DRN. Each 10-min samples were collected: five samples for baseline, one sample for during and after aggressive encounter, and five further samples after aggressive encounter. Data are mean \pm SEM expressed as percentage of baseline $(n=$ $11) ;{ }^{*} p<0.05$ compared with baseline. $C$, Frequency of attack bites without and with social instigation before the surgery. The same resident males were tested for both without and with social instigation situations $\left(n=34\right.$, animals used for Experiments 6,8,9); ${ }^{*} p<0.05$. D. The frequency of attack bites without and with social instigation during in vivo microdialysis experiment. Different animals were assigned to either without instigation group $(n=25$, Experiments 5,7$)$ and instigation group $(n=23$, Experiments 6,8$) ;{ }^{*} p<0.05$. $\boldsymbol{E}$, Social instigation caused further increase of glutamate during aggressive encounter compared with without instigation ( $143 \%$ and $166 \%$ increase, without and with social instigation, respectively). Both social instigation and aggressive encounter increased glutamate level in the DRN. Each 10 min sample was collected: five samples for baseline, one sample for social instigation, one sample for during and after aggressive encounter, and five further samples after aggressive encounter. Data are mean \pm SEM expressed as percentage of baseline $(n=10) ;{ }^{*} p<0.05$ compared with baseline.

input in the DRN and the level of aggressive behavior, because (1) direct injection of L-glutamate into the DRN increased intermale aggression in mice in a dose-dependent manner, and (2) the increase of glutamate release in the DRN was higher in the instigation-heightened aggression than during species-typical aggression without social instigation. Glutamate input in the DRN also increased during the period of social instigation, where the mouse can see, hear, and smell another male but cannot perform any aggressive behavior. Thus, the increase of glutamate in the DRN corresponds to both provocation (initiation) and execution of aggressive behavior. The precise role of this glutamate input as the basis for the motivational aspects of escalated aggressive behavior, as well as its relationship to stress responses, remains to be clarified in the future.

In the microinjection experiment, we found that the aggression-heightening effect of L-glutamate showed systematic dose-dependency in the low-dose range $(0.1-1.0 \mu \mathrm{M})$, but disappeared at higher doses $(>100 \mu \mathrm{M})$. The extracellular level of glutamate in rat hippocampus or striatum was estimated $\sim 1-3 \mu \mathrm{M}$ in vivo (Lerma et al., 1986; Baker et al., 2002), or $25 \mathrm{~nm}$ in vitro (Herman and Jahr, 2007). In our study, the basal extracellular glutamate concentration in the mouse DRN was estimated $\sim 0.31$ $\mu \mathrm{M}( \pm 0.16 \mu \mathrm{M})$, and it increased during the aggressive behavior to $0.46 \mu \mathrm{M}( \pm 0.22 \mu \mathrm{M})$. Therefore, the effective dose range of L-glutamate on aggressive behavior in our study was very close to the physiological range of glutamate in the DRN. Although it is known that excessive levels of glutamate can induce excitotoxicity and induce cellular necrosis or apoptosis (Bonfoco et al., 1995), the doses of L-glutamate that had proaggressive effects in our study were much lower than the doses that may have neurotoxic effects (20 $\mu$ m; Iriyama et al., 2009).

\section{Differences in 5-HT release between species-typical aggression and escalated aggression}

Previous studies showed that in male rats, 5-HT release in the $\mathrm{mPFC}$ was reduced during the termination of an aggressive encounter, and was also reduced in the nucleus accumbens during anticipation of an aggressive episode (van Erp and Miczek, 2000; Ferrari et al., 2003). In the present study, 5-HT release in the DRN and $\mathrm{mPFC}$ of male mice did not change during species-typical aggressive encounters. The difference may be attributable to species differences (rat vs mouse) in 5-HT function on aggression. In addition, our 10 min dialysate sample for each aggressive encounter included both the 2 min encounter and an additional 8 min after the aggression ended. Because we found a delayed increase of extracellular 5-HT in the DRN after aggressive encounters (Fig. $5 \mathrm{~A}$ ), it is possible that a slight reduction of 5-HT during aggressive behavior may be counterbalanced by an increase in 5-HT release afterward or vice versa. In any case, these results indicate that there is either a reduction or no change of 5-HT release when rodents engage in species-typical aggression. On the other hand, when animals engage in escalated aggression, we ob- 

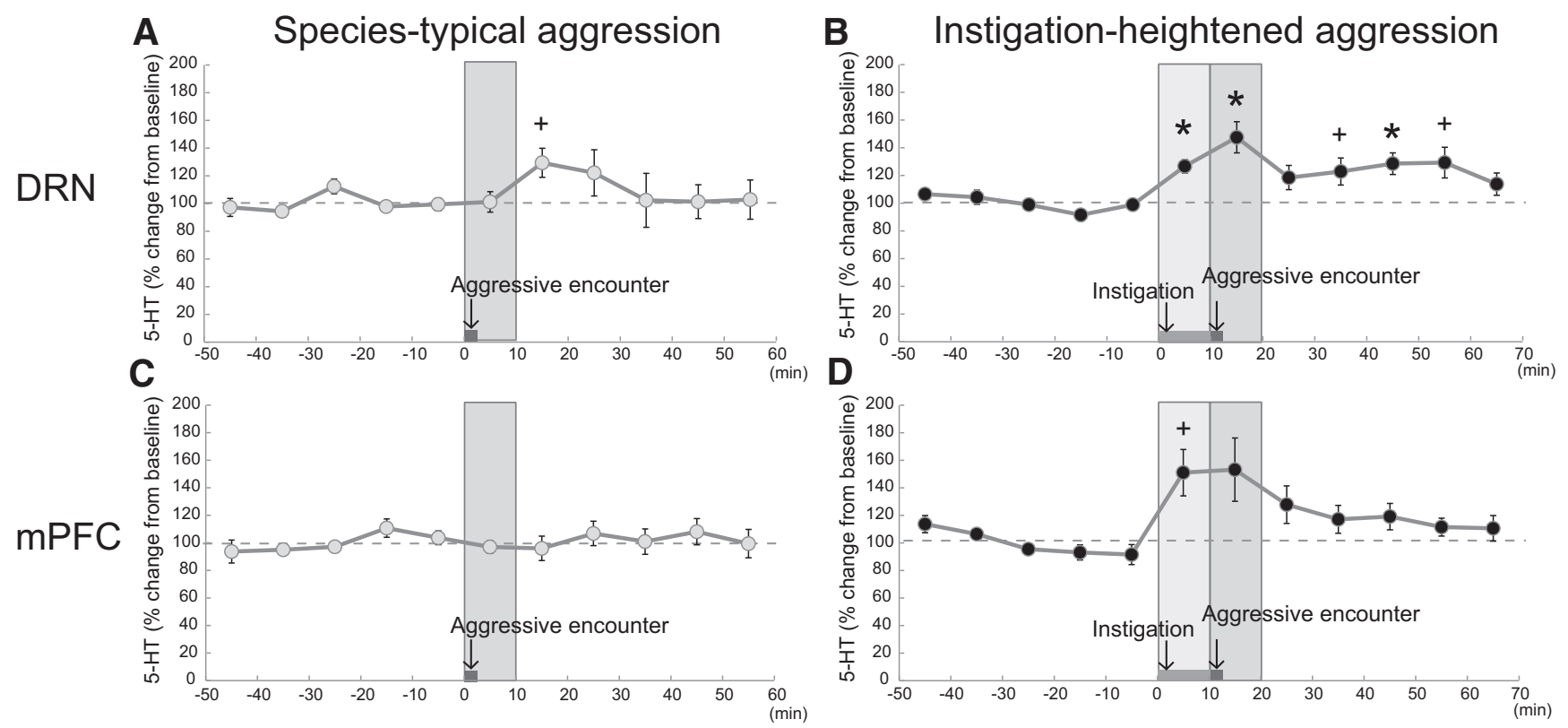

Figure 5. 5-HT release in the DRN and the mPFC evoked by aggressive encounter and instigation-heightened aggression. $A$, Aggressive encounter without instigation did not change the 5 -HT level in the DRN $(n=11)$. However, there was delayed increase of 5-HT $10-20$ min after the aggressive encounter. B, Social instigation caused increases of 5-HT release in the DRN during the social instigation and during and after the instigation-heightened aggression $(n=11)$. C, There was not change of 5 -HT in the mPFC during aggressive encounter without social instigation $(n=9)$. $\boldsymbol{D}$, Similar to the DRN, social instigation caused increases of 5 -HT release in the mPFC during the social instigation and during and after instigation heightened aggression ( $n=8$ ). Each 10 min sample was collected: five samples for baseline, one sample for during and after aggressive encounter, and five further samples after aggressive encounter for species-typical aggression, subsequent five samples for base line, one sample for social instigation, one sample for during and after aggressive encounter, and five further samples after aggressive encounter for instigation-heightened aggression. Data are mean \pm SEM expressed as percentage of baseline; ${ }^{*} p<0.05$ (with Bonferroni correction), $+p<0.005$ (without Bonferroni correction) compared with baseline.

served a significant increase in 5-HT release in both the DRN and the mPFC. This result is consistent with our previous finding that an aggression-heightening dose of baclofen microinjected into the DRN caused an increase of 5-HT release in the MPFC (Takahashi et al., 2010b). Thus, in contrast to species-typical aggression, a phasic increase of 5-HT release seems to be linked to escalated level of aggression induced by social instigation.

In the present study, a direct injection of L-glutamate into the DRN escalated aggression, and there was also a significant increase in glutamate in the DRN during instigation-heightened aggression. These results indicate that an enhancement of glutamatergic input into the DRN activates 5-HT neurons, and leads to escalated aggression in male mice. On the other hand, we also observed a smaller but still statistically significant increase of glutamatergic input in the DRN during species-typical aggression. Because 5-HT release was not increased during the same period of time, it is likely that the glutamate inputs during species-typical aggression and instigation-heightened aggression are qualitatively different. In other words, different sets of glutamatergic projections into the DRN may be activated during different types of aggression. Several brain areas send glutamatergic projections to the DRN with different topological organization (Lee et al., 2003; Crawford et al., 2011; Sego et al., 2014). The mPFC is one of the areas that send dense glutamatergic projections to the DRN. The optogenetic activation of the terminals of mPFC excitatory projections in the DRN activates GABA interneurons, and therefore inhibits 5-HT neural activities (Challis et al., 2014). This pathway has been shown to be involved in the reduction of social interaction in defeated animals (Challis et al., 2013, 2014). Also, optogenetic activation of mPFC excitatory neurons can inhibit aggressive behavior of male mice (Takahashi et al., 2014). Thus, the effect of glutamatergic input from mPFC on aggressive behavior or active social approach seems to be not excitatory, but rather inhibitory. Many other areas, such as the habenula, hypothalamic areas, extended amygdala, basal ganglia, and periaqueductal gray also send glutamatergic input into the DRN (Piñeyro and Blier, 1999, Ogawa et al., 2014). Further study will be required to dissect which glutamatergic input is linked to speciestypical aggression and escalated aggression.

Some studies have shown that the inhibition of the 5-HT system causes an escalation of aggressive behavior (Hendricks et al., 2003; Mosienko et al., 2012; Audero et al., 2013). On the other hand, our results indicated that 5-HT release increased when mice engaged in escalated aggression after social instigation, and demonstrated that the phasic change of DRN 5-HT release differs depending on the types of aggression. In the future, we plan to examine which activation pattern or inhibition of the 5-HT system can affect which type of aggression.

\section{Notes}

Supplemental material for this article is available at http://www.nig.ac. jp/labs/MGRL/Supplemental Figs1_2.pdf. Supplemental Figure 1 shows representative pictures of the DRN with baclofen injection (A), with L-glutamate injection (B), and in vivo microdialysis (C). Also, the representative picture of the $\mathrm{mPFC}$ with in vivo microdialysis (D). Supplemental Figure 2 shows microinjection of several doses of L-glutamate into the DRN on the frequency of attack bites. Values are mean \pm SEM. $p$ value by $t$ test was provided for $0.001 \mathrm{~mm}$ L-glutamate compared with vehicle control. This material has not been peer reviewed.

\section{References}

Abellán MT, Jolas T, Aghajanian GK, Artigas F (2000) Dual control of dorsal raphe serotonergic neurons by $\mathrm{GABA}_{\mathrm{B}}$ receptors: electrophysiological and microdialysis studies. Synapse 36:21-34. CrossRef Medline

Adell A, Celada P, Abellán MT, Artigas F (2002) Origin and functional role of the extracellular serotonin in the midbrain raphe nuclei. Brain Res Rev 39:154-180. CrossRef Medline

Arakawa H, Suzuki A, Zhao S, Tsytsarev V, Lo FS, Hayashi Y, Itohara S, 
Iwasato T, Erzurumlu RS (2014) Thalamic NMDA receptor function is necessary for patterning of the thalamocortical somatosensory map and for sensorimotor behaviors. J Neurosci 34:12001-12014. CrossRef Medline

Audero E, Mlinar B, Baccini G, Skachokova ZK, Corradetti R, Gross C (2013) Suppression of serotonin neuron firing increases aggression in mice. J Neurosci 33:8678-8688. CrossRef Medline

Bagdy E, Kiraly I, Harsing LG Jr (2000) Reciprocal innervation between serotonergic and GABAergic neurons in raphe nuclei of the rat. Neurochem Res 25:1465-1473. CrossRef Medline

Baker DA, Xi ZX, Shen H, Swanson CJ, Kalivas PW (2002) The origin and neuronal function of in vivo nonsynaptic glutamate. J Neurosci 22:91349141. Medline

Bischoff S, Leonhard S, Reymann N, Schuler V, Shigemoto R, Kaupmann K, Bettler B (1999) Spatial distribution of GABA(B)R1 receptor mRNA and binding sites in the rat brain. J Comp Neurol 412:1-16. CrossRef Medline

Bonfoco E, Krainc D, Ankarcrona M, Nicotera P, Lipton SA (1995) Apoptosis and necrosis: two distinct events induced, respectively, by mild and intense insults with $\mathrm{N}$-methyl-D-aspartate or nitric oxide/superoxide in cortical cell cultures. Proc Natl Acad Sci U S A 92:7162-7166. CrossRef Medline

Burman KJ, Ige AO, White JH, Marshall FH, Pangalos MN, Emson PC, Minson JB, Llewellyn-Smith IJ (2003) $\mathrm{GABA}_{\mathrm{B}}$ receptor subunits, R1 and R2, in brainstem catecholamine and serotonin neurons. Brain Res 970:35-46. CrossRef Medline

Celada P, Puig MV, Casanovas JM, Guillazo G, Artigas F (2001) Control of dorsal raphe serotonergic neurons by the medial prefrontal cortex: involvement of serotonin-1A, $\mathrm{GABA}_{\mathrm{A}}$, and glutamate receptors. J Neurosci 21:9917-9929. Medline

Challis C, Boulden J, Veerakumar A, Espallergues J, Vassoler FM, Pierce RC, Beck SG, Berton O (2013) Raphe GABAergic neurons mediate the acquisition of avoidance after social defeat. J Neurosci 33:13978-13988. CrossRef Medline

Challis C, Beck SG, Berton O (2014) Optogenetic modulation of descending prefrontocortical inputs to the dorsal raphe bidirectionally bias socioaffective choices after social defeat. Front Behav Neurosci 8:43. CrossRef Medline

Coccaro EF, Kavoussi RJ, Cooper TB, Hauger RL (1997) Central serotonin activity and aggression: inverse relationship with prolactin response to d-fenfluramine, but not CSF 5-HIAA concentration, in human subjects. Am J Psychiatry 154:1430-1435. CrossRef Medline

Colmers WF, Williams JT (1988) Pertussis toxin pretreatment discriminates between pre- and postsynaptic actions of baclofen in rat dorsal raphe nucleus in vitro. Neurosci Lett 93:300-306. CrossRef Medline

Crawford LK, Craige CP, Beck SG (2011) Glutamatergic input is selectively increased in dorsal raphe subfield 5-HT neurons: role of morphology, topography and selective innervation. Eur J Neurosci 34:1794-1806. CrossRef Medline

Cruz HG, Ivanova T, Lunn ML, Stoffel M, Slesinger PA, Lüscher C (2004) Bi-directional effects of $\mathrm{GABA}_{\mathrm{B}}$ receptor agonists on the mesolimbic dopamine system. Nat Neurosci 7:153-159. CrossRef Medline

de Boer SF, Koolhaas JM (2005) 5- $\mathrm{HT}_{1 \mathrm{~A}}$ and 5- $\mathrm{HT}_{1 \mathrm{~B}}$ receptor agonists and aggression: a pharmacological challenge of the serotonin deficiency hypothesis. Eur J Pharmacol 526:125-139. CrossRef Medline

Ferrari PF, van Erp AM, Tornatzky W, Miczek KA (2003) Accumbal dopamine and serotonin in anticipation of the next aggressive episode in rats. Eur J Neurosci 17:371-378. CrossRef Medline

Fish EW, Faccidomo S, Miczek KA (1999) Aggression heightened by alcohol or social instigation in mice: reduction by the $5-\mathrm{HT}_{1 \mathrm{~B}}$ receptor agonist CP-94,253. Psychopharmacology (Berl) 146:391-399. CrossRef Medline

Franklin K, Paxinos G (2008) The mouse brain in stereotaxic coordinates, Ed 3. San Diego: Academic.

Grant EC, Mackintosh JH (1963) A comparison of the social postures of some common laboratory rodents. Behaviour 21:246-259. CrossRef

Hale MW, Lowry CA (2011) Functional topography of midbrain and pontine serotonergic systems: implications for synaptic regulation of serotonergic circuits. Psychopharmacology (Berl) 213:243-264. CrossRef Medline

Haller C, Casanova E, Müller M, Vacher CM, Vigot R, Doll T, Barbieri S, Gassmann M, Bettler B (2004) Floxed allele for conditional inactivation of the $\mathrm{GABA}_{\mathrm{B}(1)}$ gene. Genesis 40:125-130. CrossRef Medline
Hendricks TJ, Fyodorov DV, Wegman LJ, Lelutiu NB, Pehek EA, Yamamoto B, Silver J, Weeber EJ, Sweatt JD, Deneris ES (2003) Pet-1 ETS gene plays a critical role in 5-HT neuron development and is required for normal anxiety-like and aggressive behavior. Neuron 37:233-247. CrossRef Medline

Herman MA, Jahr CE (2007) Extracellular glutamate concentration in hippocampal slice. J Neurosci 27:9736-9741. CrossRef Medline

Iriyama T, Kamei Y, Kozuma S, Taketani Y (2009) Bax-inhibiting peptide protects glutamate-induced cerebellar granule cell death by blocking Bax translocation. Neurosci Lett 451:11-15. CrossRef Medline

Iwasato T, Nomura R, Ando R, Ikeda T, Tanaka M, Itohara S (2004) Dorsal telencephalon-specific expression of Cre recombinase in PAC transgenic mice. Genesis 38:130-138. CrossRef Medline

Iwasato T, Inan M, Kanki H, Erzurumlu RS, Itohara S, Crair MC (2008) Cortical adenylyl cyclase 1 is required for thalamocortical synapse maturation and aspects of layer IV barrel development. J Neurosci 28:59315943. CrossRef Medline

Jacobs BL, Cohen A (1976) Differential behavioral effects of lesions of the median or dorsal raphe nuclei in rats: open field and pain-elicited aggression. J Comp Physiol Psychol 90:102-108. CrossRef Medline

Judge SJ, Ingram CD, Gartside SE (2004) GABA receptor modulation of 5-HT neuronal firing: characterization and effect of moderate in vivo variations in glucocorticoid levels. Neurochem Int 45:1057-1065. CrossRef Medline

Kobayashi Y, Sano Y, Vannoni E, Goto H, Suzuki H, Oba A, Kawasaki H, Kanba S, Lipp HP, Murphy NP, Wolfer DP, Itohara S (2013) Genetic dissection of medial habenula-interpeduncular nucleus pathway function in mice. Front Behav Neurosci 7:17. CrossRef Medline

Koprowska M, Romaniuk A (1997) Behavioral and biochemical alterations in median and dorsal raphe nuclei lesioned cats. Pharmacol Biochem Behav 56:529-540. CrossRef Medline

Kravitz EA, Huber R (2003) Aggression in invertebrates. Curr Opin Neurobiol 13:736-743. CrossRef Medline

Labouèbe G, Lomazzi M, Cruz HG, Creton C, Luján R, Li M, Yanagawa Y, Obata K, Watanabe M, Wickman K, Boyer SB, Slesinger PA, Lüscher C (2007) RGS2 modulates coupling between $\mathrm{GABA}_{\mathrm{B}}$ receptors and GIRK channels in dopamine neurons of the ventral tegmental area. Nat Neurosci 10:1559-1568. CrossRef Medline

Lee HS, Kim MA, Valentino RJ, Waterhouse BD (2003) Glutamatergic afferent projections to the dorsal raphe nucleus of the rat. Brain Res 963: 57-71. CrossRef Medline

Lerma J, Herranz AS, Herreras O, Abraira V, Martín del Río R (1986) In vivo determination of extracellular concentration of amino acids in the rat hippocampus: a method based on brain dialysis and computerized analysis. Brain Res 384:145-155. CrossRef Medline

Meier SD, Kafitz KW, Rose CR (2008) Developmental profile and mechanisms of GABA-induced calcium signaling in hippocampal astrocytes. Glia 56:1127-1137. CrossRef Medline

Miczek KA, O’Donnell JM (1978) Intruder-evoked aggression in isolated and nonisolated mice: effects of psychomotor stimulants and L-dopa. Psychopharmacology (Berl) 57:47-55. CrossRef Medline

Miczek KA, Faccidomo S, Fish EW, Debold JF (2007) Neurochemistry and molecular neurobiology of aggressive behavior. In: Behavioral neurochemistry, neuroendocrinology and molecular neurobiology (Blaustein J, ed), pp 285-336. New York: Springer.

Mizuno H, Luo W, Tarusawa E, Saito YM, Sato T, Yoshimura Y, Itohara S, Iwasato T (2014) NMDAR-regulated dynamics of layer 4 neuronal dendrites during thalamocortical reorganization in neonates. Neuron 82: 365-379. CrossRef Medline

Mos J, Olivier B, Poth M, Van Oorschot R, Van Aken H (1993) The effects of dorsal raphe administration of eltoprazine, TFMPP and 8-OH-DPAT on resident intruder aggression in the rat. Eur J Pharmacol 238:411-415. CrossRef Medline

Mosienko V, Bert B, Beis D, Matthes S, Fink H, Bader M, Alenina N (2012) Exaggerated aggression and decreased anxiety in mice deficient in brain serotonin. Transl Psychiatry 2:e122. CrossRef Medline

Nedergaard M, Takano T, Hansen AJ (2002) Beyond the role of glutamate as a neurotransmitter. Nat Rev Neurosci 3:748-755. CrossRef Medline

Ogawa SK, Cohen JY, Hwang D, Uchida N, Watabe-Uchida M (2014) Organization of monosynaptic inputs to the serotonin and dopamine neuromodulatory systems. Cell Reports 8:1105-1118. CrossRef Medline

Piñeyro G, Blier P (1999) Autoregulation of serotonin neurons: role in antidepressant drug action. Pharmacol Rev 51:533-591. Medline 
Sego C, Gonçalves L, Lima L, Furigo IC, Donato J Jr, Metzger M (2014) Lateral habenula and the rostromedial tegmental nucleus innervate neurochemically distinct subdivisions of the dorsal raphe nucleus in the rat. J Comp Neurol 522:1454-1484. CrossRef Medline

Serrats J, Artigas F, Mengod G, Cortés R (2003) $\mathrm{GABA}_{\mathrm{B}}$ receptor mRNA in the raphe nuclei: co-expression with serotonin transporter and glutamic acid decarboxylase. J Neurochem 84:743-752. CrossRef Medline

Soiza-Reilly M, Anderson WB, Vaughan CW, Commons KG (2013) Presynaptic gating of excitation in the dorsal raphe nucleus by GABA. Proc Natl Acad Sci U S A 110:15800-15805. CrossRef Medline

Suzuki A, Lee LJ, Hayashi Y, Muglia L, Itohara S, Erzurumlu RS, Iwasato T (2015) Thalamic adenylyl cyclase 1 is required for barrel formation in the somatosensory cortex. Neuroscience 290:518-529. CrossRef Medline

Takahashi A, Kwa C, Debold JF, Miczek KA (2010a) GABA A receptors in the dorsal raphé nucleus of mice: escalation of aggression after alcohol consumption. Psychopharmacology (Berl) 211:467-477. CrossRef Medline

Takahashi A, Shimamoto A, Boyson CO, DeBold JF, Miczek KA (2010b) $\mathrm{GABA}_{\mathrm{B}}$ receptor modulation of serotonin neurons in the dorsal raphe nucleus and escalation of aggression in mice. J Neurosci 30:11771-11780. CrossRef Medline

Takahashi A, Schilit AN, Kim J, Debold JF, Koide T, Miczek KA (2012) Behavioral characterization of escalated aggression induced by $\mathrm{GABA}_{\mathrm{B}}$ receptor activation in the dorsal raphe nucleus. Psychopharmacology (Berl) 224:155-166. CrossRef Medline

Takahashi A, Nagayasu K, Nishitani N, Kaneko S, Koide T (2014) Control of intermale aggression by medial prefrontal cortex activation in the mouse. PLoS One 9:e94657. CrossRef Medline

Tao R, Ma Z, Auerbach SB (1996) Differential regulation of 5-hydroxytryptamine release by $\mathrm{GABA}_{\mathrm{A}}$ and $\mathrm{GABA}_{\mathrm{B}}$ receptors in midbrain raphe nuclei and forebrain of rats. Br J Pharmacol 119:1375-1384. CrossRef Medline

van der Vegt BJ, Lieuwes N, van de Wall EH, Kato K, Moya-Albiol L, Martínez-Sanchis S, de Boer SF, Koolhaas JM (2003) Activation of serotonergic neurotransmission during the performance of aggressive behavior in rats. Behav Neurosci 117:667-674. CrossRef Medline

van Erp AM, Miczek KA (2000) Aggressive behavior, increased accumbal dopamine, and decreased cortical serotonin in rats. J Neurosci 20:9320 9325. Medline

Varga V, Kocsis B, Sharp T (2003) Electrophysiological evidence for convergence of inputs from the medial prefrontal cortex and lateral habenula on single neurons in the dorsal raphe nucleus. Eur J Neurosci 17:280-286. CrossRef Medline

Vergnes M, Depaulis A, Boehrer A (1986) Parachlorophenylalanineinduced serotonin depletion increases offensive but not defensive aggression in male rats. Physiol Behav 36:653-658. CrossRef Medline

Walletschek H, Raab A (1982) Spontaneous activity of dorsal raphe neurons during defensive and offensive encounters in the tree-shrew. Physiol Behav 28:697-705. CrossRef Medline

Wirtshafter D, Sheppard AC (2001) Localization of $G_{A B A}$ receptors in midbrain monoamine containing neurons in the rat. Brain Res Bull 56: 1-5. CrossRef Medline 